\section{Propagation of Tronchuda (Brassica oleracea var. tronchuda Bailey) from Cuttings}

\author{
W. Msikita ${ }^{1}$, H.T. Wilkinson ${ }^{2}$, and R.M. Skirvin ${ }^{3}$ \\ University of Illinois, Urbana, IL 61801
}

Additional index words. asexual propagation, cultivars

\begin{abstract}
A system to propagate tronchuda (Brassica oleracea var. tronchuda Bailey syn. costata $\mathbf{L}$.) from main stem and side shoot cuttings was developed by removing the main stem (three to four leaves) and, later, side shoots from S-week-old plants, transplanting them into small pots, and growing them under a mist system for 4 weeks. New root growth appeared on cuttings within 3 weeks. Rooting frequency varied among cultivars and explant types. For all cultivars, side shoot cuttings rooted better than main stem cuttings $(99.7 \%$ vs. $84.8 \%)$. For all cultivars, seed-propagated plants and side shoot cuttings produced leaves with significantly higher fresh weight than the main stem cuttings for three of the five cultivars. The average number of leaves per plant for four cultivars was, however, not significantly affected by propagation method. Average leaf count and fresh weight per plant were significantly higher for 'Portuguesa' than for 'Ana Maria'. 'Couve Penca'. 'Vilinda', and 'Penca de Chaves' for all three propagation sources.
\end{abstract}

Leafy cruciferae vegetable crops such as tronchuda are traditionally propagated sexually from seed. A disadvantage of sexual propagation is the lengthy reproductive cycle for biennial species. A long reproductive cycle is particularly undesirable if few seeds are produced and there is a need to rapidly increase seed stock. Tissue culture can reduce the time required to multiply plants (Murashige, 1974); however, it is complicated by the need to develop an appropriate tissue culture propagation system. Conventional vegetative propagation using cuttings can provide a simple, rapid, and inexpensive alternative.

Tronchuda is a biennial, leafy vegetable crop believed to be a cross between Brassica oleracea var. capitata and B. oleracea var.

Received for publication 18 Nov. 1991. Accepted for publication 27 Mar. 1992. This research was supported in part by the Univ. of Illinois Agricultural Experiment Station (Hatch NC 1250332); the Illinois Turfgrass Assn., Chicago; and the MidAmerica Sod Growers Assn. of Illinois, Chicago. We thank W.L. Pedersen for assistance with the statistical analyses, and the Vegetable Crops Research Team, Mazabuka, Zambia, for the seed samples. The cost of publishing this paper was defrayed in part by the payment of page charges. Under postal regulations, this paper therefore must be hereby marked advertisement solely to indicate this fact.

'Graduate Research Assistant, Dept. of Plant Pathology.

${ }^{2}$ Associate Professor of Plant Pathology and Agronomy.

${ }^{3}$ Professor, Dept. of Horticulture. acephala (Msikita and Skirvin, 1989). Hortus Third describes it as "a cabbage-like plant, without compact heads of leaves, with fleshy petioles and broad midribs" (Liberty Hyde tugal, where it is native (Miguel, 1957), tronchuda is cultivated in contiguous areas with Portuguese influence (Msikita and Skirvin, 1989). Tronchuda has wide adaptation, producing $1.6 \mathrm{t}$ seed/ha in a subtropical climate (Msikita and Mnzava, 1988); it has resistance to turnip mosaic virus, an ubiquitous pathogen (Asian Vegetable Research Center, 198.5) of Brassica and other plant species (Mingochi and Jensen, 1988).

In preliminary studies, we observed that tronchuda can be propagated from side shoots without the use of root-inducing chemicals. This study was undertaken to ascertain the potential of using tronchuda main stem and side shoot cuttings to asexually propagate the plant.

Seeds of five cultivars of tronchuda ('Portuguesa', 'Vilinda', 'Couve Penca', 'Penca de Chaves', and 'Ana Maria'), obtained from Zambia (the Vegetable Crops Research Team, Mazabuka), were sown (1 $\mathrm{cm}$ deep) in a growth medium of 1 sterilized peat : 1 perlite : 1 soil (by volume), contained in 0.15 .liter plastic pots maintained in a greenhouse $(25 \mathrm{C}$, natural light), and watered as needed to maintain a moist medium.

Three weeks after germination, 18 vigorous seedlings of each cultivar were selected and transplanted into 10-liter plastic pots containing the growth medium described Bailey Hortorium, 1976). Other than Por- above plus a $14 \mathrm{~N}-14 \mathrm{P}-14 \mathrm{~K}$ slow-release Osmocote (Sierra Chemical, Milpitas, Calif.) fertilizer ( $1 \mathrm{~g} /$ liter of medium).

Two weeks after transplanting, the apical region, including three to four nodes, was excised with a sterilized scalpel that had been immersed in $80 \%$ ethanol. The cuttings (main stem) were trimmed until only the two youngest leaves remained. Each shoot was transplanted into a 0.15 -liter plastic pot containing the growth medium and maintained for 4 weeks under moist conditions using an overhead mist system (5 sec mist every 5 min). Twelve main stem cuttings were obtained for each cultivar.

Rapid Gro (Chevron Chemical, San Ramon, Calif.) plant nutrient solution ( $2 \mathrm{~g} 23 \mathrm{~N}$ 19P-17K/liter, $100 \mathrm{ml} /$ pot) was applied biweekly to each of the intact (seed-propagated) control plants and remnants of the decapitated plants (stumps) for the entire experimental period. Control plants and stumps were regularly watered to maintain a moist medium.

Two vigorous side shoots on each stump were removed at the three- to four-leaf stage, transplanted, and grown under the moist conditions as described for main stem cuttings. After 3 weeks, cuttings were observed for root formation. Rooted cuttings were transplanted into lo-liter pots (one transplant per pot), and Rapid Gro plant solution was applied 1 week later as described above. When necessary, insecticidal soap was applied to control aphids and white flies.

Mature, nonsenescing leaves from all treatments were first harvested $\approx 4$ weeks after transplanting to large pots. Leaves were harvested weekly thereafter, until plants senesced or produced small-sized leaves. Leaf yield for each of the five cultivars was recorded as the number of leaves and the total fresh weight per plant.

The experimental unit consisted of three to six plants per observation for each cultivar, replicated four times in a split-plot design with cultivars assigned to main plots

Table 1. Rooting ability of tronchuda cultivars propagated from cuttings.

\begin{tabular}{lcc}
\hline \hline & \multicolumn{2}{c}{ Cuttings with roots (\%) } \\
\cline { 2 - 3 } Cultivar & $\begin{array}{c}\text { Main } \\
\text { stem }\end{array}$ & $\begin{array}{c}\text { Side } \\
\text { shoot }^{x}\end{array}$ \\
\hline Portuguesa & 80.2 & 100 \\
Vilinda & 80.0 & 98.6 \\
Couve Penca & 96.0 & 100 \\
Ana Maria & 90.0 & 100 \\
Penca de Chaves & 88.0 & 100 \\
LSD (0.05) & 9.4 & 1.2 \\
\hline
\end{tabular}

${ }^{2} \mathrm{n}=96$ cuttings/cultivar for two experiments. ${ }^{y} \mathrm{n}=24$ cuttings/cultivar for two experiments

${ }^{x}$ Percentage of cuttings rooted (at least $1 \mathrm{~cm}$ long) after 4 weeks under misting. 
Table 2. Analysis of variance for fresh leaf weights of tronchuda ( $\mathrm{n}=360$ to 720 ).

\begin{tabular}{|c|c|c|c|c|c|}
\hline Source & $\mathrm{df}$ & SS & MS & $\mathrm{F}$ & $P$ \\
\hline $\begin{array}{l}\text { Replication } \\
\text { Cultivars }\end{array}$ & $\begin{array}{l}3 \\
4\end{array}$ & $\begin{array}{r}34,445 \\
2,429,736\end{array}$ & 607,434 & $\overline{77.3}$ & 0.0001 \\
\hline Rep. $\times$ cultivar & & & & & ... \\
\hline Propagation methods & $\begin{array}{r}12 \\
2\end{array}$ & $\begin{array}{r}088,9 / 4 \\
78,357\end{array}$ & 39,179 & 4.9 & 0.013 \\
\hline $\begin{array}{l}\text { Cultivars } \times \\
\text { propagation }\end{array}$ & 8 & 115,987 & 14,498 & 3.1 & 0.017 \\
\hline $\begin{array}{l}\text { Rep. } \times \text { propagation }+ \\
\text { rep. } \times \text { propagation } \times \\
\text { cultivar (Error } B)\end{array}$ & 30 & 138,963 & 4,632 & $\cdots$ & --- \\
\hline
\end{tabular}

Table 3. Mean fresh leaf weight per plant of tronchuda propagated asexually or by seed $(\mathrm{n}=360 \text { to } 720)^{\mathrm{z}}$

\begin{tabular}{|c|c|c|c|}
\hline \multirow[b]{2}{*}{ Cultivar } & \multicolumn{3}{|c|}{ Propagation method } \\
\hline & Seed & $\begin{array}{l}\text { Main } \\
\text { stem }\end{array}$ & $\begin{array}{c}\text { Side } \\
\text { shoots }\end{array}$ \\
\hline & \multicolumn{3}{|c|}{ Leaf wt $(g)$} \\
\hline Portuguesa & 1041 & 984 & 1009 \\
\hline Vilinda & 621 & 441 & 576 \\
\hline Courve Penca & 555 & 484 & 477 \\
\hline Penca de Chaves & 495 & 500 & 361 \\
\hline Ana Maria & 621 & 490 & 638 \\
\hline $\begin{array}{l}\text { Cultivar } \times \\
\text { propagation } \\
\text { method }\end{array}$ & * & & \\
\hline
\end{tabular}

${ }^{2}$ Data are means of the fresh weight $(\mathrm{g})$ of all leaves on a stem. LSD $(0.05)=311.9$ for comparing cultivars using the same propagation method. LSD $(0.05)=98.3$ for comparing the propagation methods for each cultivar.

Table 4. Mean number of leaves per plant of tronchuda propagated asexually or by seed ( $\mathrm{n}=360$ to 720$)$.

\begin{tabular}{|c|c|c|c|}
\hline \multirow[b]{2}{*}{ Cultivar } & \multicolumn{3}{|c|}{ Propagation method } \\
\hline & Seed & $\begin{array}{l}\text { Main } \\
\text { stem }\end{array}$ & $\begin{array}{l}\text { Side } \\
\text { shoots }\end{array}$ \\
\hline Portuguesa & 64 & 60 & 52 \\
\hline Vilinda & 26 & 25 & 28 \\
\hline Couve Penca & 23 & 23 & 24 \\
\hline Penca de Chaves & 19 & 23 & 19 \\
\hline Ana Maria & 32 & 31 & 29 \\
\hline \multicolumn{4}{|l|}{ Cultivar $x$} \\
\hline propagation method & * & & \\
\hline
\end{tabular}

LSD $(0.05)=17.36$ for comparing among cultivars using the same propagation method. LSD $(0.05)=11.48$ for comparing the propagation methods for each cultivar.

* Significant at $P=0.05$.

Table 5. Mean leaf size of tronchuda propagated asexually and by seed ( $\mathrm{n}=360$ to 720 ).

\begin{tabular}{lccc}
\hline \hline & \multicolumn{3}{c}{ Propagation method } \\
\cline { 2 - 4 } Cultivar & Seed & $\begin{array}{c}\text { Main } \\
\text { stem }\end{array}$ & $\begin{array}{c}\text { Side } \\
\text { shoots }\end{array}$ \\
\hline & \multicolumn{3}{c}{ Leaf size } \\
Portuguesa & 16.3 & 16.4 & 19.4 \\
Vilinda & 23.9 & 17.6 & 20.6 \\
Couve Penca & 24.1 & 21.0 & 20.0 \\
Penca de Chaves & 26.1 & 21.7 & 19.0 \\
Ana Maria & 19.4 & 15.8 & 22.3 \\
\hline
\end{tabular}

'Ratio of mean fresh leaf weight to mean number per plant. LSD $(0.05)=1.07$ for comparing among cultivars using the same propagation method. LSD $(0.05)=5.37$ for comparing the propagation methods for each cultivar. and propagation methods to subplots. Amongand within-cultivar comparisons were made for the number of leaves and the mean fresh leaf weights for each of the control, main, and side shoot cuttings. The experiment was repeated, data were analyzed using analysis of variance, and means were separated using the appropriate error terms according to Carmer and Walker (1982).

All cultivars produced roots that attained a length of $\gg 5 \mathrm{~cm}$ within 19 to 21 days after transplanting. The percentage of cuttings that rooted was 10 to 20 percentage points higher for side shoots than for main-stem cuttings for all cultivars (Table 1). From main stems, 'Couve Penca' rooted significantly better than the other cultivars. After being transplanted into 10-liter pots and receiving nutrient solution, all three propagative types grew vigorously, and their leaves were of good quality (size, fresh weight).

Cultivars differed significantly in leaf fresh weight (Tables 2 and 3). Seed-propagated plants mostly produced heavier leaves than main and side shoot-derived plants. 'Penca de Chaves' and 'Ana Maria' produced leaves of slightly higher fresh weight per plant from main and side shoots, respectively, but the differences were nonsignificant. Mean fresh leaf weight for main shoot-derived plants for 'Penca de Chaves' was similar to that of seedpropagated plants, but higher than that for side shoot-derived plants, in contrast to treatment hierarchies among other cultivars. 'Portuguesa' consistently produced significantly heavier (Table 3) leaves than the other four cultivars for each propagation method. With the exception of 'Portuguesa', the interaction of cultivars and propagation methods were nonsignificant for leaf fresh weight per plant (Tables 2 and 3).

The mean number of leaves per plant was similar for each of the three propagation methods for all cultivars, except 'Portuguesa', which produced about twice as many leaves per plant as any other cultivars (Table 4). With the exception of 'Portuguesa', the interaction of cultivars and propagation methods was nonsignificant for leaf count per plant (Table 4).

Variation in leaf size (fresh leaf weight per leaf) among the cultivars was observed (Table 5). The greatest variation was with seed propagation. With this method, 'Penca de Chaves' produced significantly larger leaves than any other cultivar. Using the main stem, the leaf sizes produced by 'Couve Penca' and 'Penca de Chaves' were similar, but significantly larger than those of the other cul- tivars. For side shoot-propagated plants, "Ana Maria' produced leaves significantly larger than any other cultivar, and 'Penca de Chaves' produced significantly smaller leaves than all but 'Portuguesa' and 'Couve Penca'.

Only two cultivars responded differently in terms of leaf size to the three propagation methods. 'Penca de Chaves' produced significantly larger leaves using seed than sideshoot propagation, and 'Ana Maria' produced significantly larger leaves with sideshoot than with main-stem propagation (Table 5).

Cultivars varied in their ability to root from cuttings; main stem cuttings rooted less often than side shoots. Main stem cuttings were generally large in diameter and succulent at the time of transplanting compared with side shoot cuttings. Succulence might account for the low rooting frequency from main stem cuttings. The manipulation of moisture or nutrients in the rooting medium or the use of exogenous growth regulators could increase the rooting capacity of main shoots (Creelman, 1989).

The subsequent leaf yields of plants propagated from cuttings varied significantly by cultivar and propagation method. Overall, 'Portuguesa' was the best yielding in both leaf count and fresh leaf weight per plant. The high performance of 'Portuguesa' was consistent with earlier reports from field studies (Msikita and Mnzava, 1988) and might indicate the cultivar's wide adaptability and/ or its short plastochron and efficient use of photosynthate to initiate new leaves.

The variation in the number of leaves per plant among the propagation sources and the interaction of cultivars and propagation method were nonsignificant for most cultivars, except 'Portuguesa'. This result might indicate that others have good potential as propagative materials. However, the significant variation among cultivars and propagation sources in leaf sizes might be due to variation in developmental status and/or cultivar response to management factors at the time of explanting.

This study demonstrates the potential for propagating tronchuda from main stem and side shoot cuttings. We recommend side shoot and main stem cuttings as alternative propagation materials for tronchuda. Propagation from side shoot and main stem cuttings is potentially useful to growers and breeders who may wish to rapidly produce true-totype, uniform plants without waiting for seed to form and mature. This system also is relatively inexpensive, as it does not require the use of rooting agents.

\section{Literature Cited}

Asian Vegetable Research Center. 1985. Host reaction of five Taiwan strains of turnip mosaic virus (TuMV). 1983 Progress Rpt. Asian Veg. Res. and Dev. Ctr., Tainan, Taiwan. p. 113-117. Carmer, S.G. and W.M. Walker. 1982. Formulae for least significant differences for split-plot, split-block and split-split-plot experiments. Univ. of Illinois, Tech. Rpt. 10:1-8.

Creelman, R.A. 1989. Absicic acid physiology and biosynthesis in higher plants. Physiol. Plant. $75: 131-136$ 
Liberty Hyde Bailey Hortorium. 1976. Hortus third: A concise dictionary of plants cultivated in the United States and Canada. 3rd. ed. Macmillan, New York

Miguel, M.C. 1957. "Varieties of "tronchuda" or veined cabbages. Proc. Intl.. Seed Test. Assn. 22:1-16.

Mingochi, D.S. and A. Jensen. 1988. Reaction of rape and Ethiopian mustard selections to black- rot and turnip mosaic virus (TuMV) in Zambia. Acta Hort. 218:289-294.

Mnzava, N.A. and W. Msikita. 1988. Leaf yield response of Ethiopian mustard (Brassica carinata A. Br.) selections to defoliation regimes. Acts. Hort. 218:77-82.

Msikita, W. and Mnzava, N.A. 1988. Comparative field performance of mustard, tronchuda and kale during mild winters in Zambia. Acts Hort. 218:59-64.

Msikita, W. and R.M. Skirvin. 1989. In vitro regeneration from hypocotyl and seedling cotyledons of tronchuda (Brassica oleracea var. tronchuda Bailey). Plant cell Tissue \& Organ Culture 19:159-165.

Murashige, T. 1974. Plant propagation through tissue culture. Annu. Rev. Plant Physiol. 25:135165 . 